Saudi Journal of Biomedical Research

Abbreviated Key Title: Saudi J Biomed Res ISSN 2518-3214 (Print) IISSN 2518-3222 (Online)

\title{
Anti-Diarrheal Evaluation of the Aqueous Ethanol Extract of Jateorhiza macrantha (Hook F.) Exell Mendonça (Menispermaceae) Leaves
}

\author{
Onyejekwe V. N, Afieroho OE*', Abo KA \\ Department of Pharmacognosy and Phytotherapy, University of Port Harcourt, Nigeria
}

DOI: $10.36348 /$ sjbr.2020.v05i02.004 | Received: 04.02.2020| Accepted: 11.02.2020 | Published: 29.02 .2020

*Corresponding author: Afieroho OE

\section{Abstract}

Jateorhiza macrantha is a medicinal plant used in ethnomedicine for dysentery, cough, boil, ulcer, and inflammation, wound healing and venomous bite. This study is aimed at evaluating the anti-diarrheal activity of the aqueous ethanol extract from the leaves of Jateorhiza macrantha. The aqueous ethanol extract (AEE) was obtained by exhaustive cold maceration in 70\% aqueous. The anti-diarrheal and anti-motility activities of the AEE were evaluated using the castor oil induced diarrheal and charcoal meal animal assays respectively. Loperamide $(2 \mathrm{mg} / \mathrm{kg}$ bw) and atropine sulphate (5 $\mathrm{mg} / \mathrm{kg} \mathrm{bw}$ ) were used as reference anti-diarrheal and anti-motility agents respectively for comparison. The AEE shows dose dependent anti-diarrheal and anti-motility activities. The trend in the anti-diarrheal activity (\% inhibition of fecal mass compared to negative control group): loperamide-2mg/kgbw (67.42\%)> AEJML-400mg/kgbw (64.49\%)>AEJML$200 \mathrm{mg} / \mathrm{kgbw}(41.57 \%)>$ AEJML-100mg/kgbw (13.48\%) and anti-motility (\% inhibition of intestinal peristalsis index compared to negative control group): AEJML-250mg/kgbw(71.70\%)>AEJML-125mg/kgbw(30.10\%)>AEJML$100 \mathrm{mg} / \mathrm{kgbw}(0.37 \%)$. The trend in anti-castor oil induced diarrheal and anti-motility activities obtained in this study for Jateorhiza macrantha justifies its use in ethno medicine for the treatment of diarrheal and related gas intestinal tracts illness.

Keywords: Jateorhiza macrantha, Menispermaceae, anti-diarrheal activity, anti-motility, anti-cholinergic, drug discovery.

Copyright @ 2020: This is an open-access article distributed under the terms of the Creative Commons Attribution license which permits unrestricted use, distribution, and reproduction in any medium for non-commercial use (NonCommercial, or CC-BY-NC) provided the original author and source are credited.

\section{INTRODUCTION}

Diarrhea is a disease of the gastro-intestinal tract (GIT) characterized by frequent increase of bowel movement, wet stool and abdominal pain [1]. It is a major cause of death among young babies below five years in undeveloped countries globally [2]. It has been reported that 57800 out of 6.3 million children below five years died of diarrheal related illnesses in Africa [3]. The high rate of mortality in infants due to diarrheal infection, and the high cost of orthodox medicine has resulted to the return to traditional medicine by the global population as an alternative to orthodox medicine. Medicinal plants still remain a source of novel pharmacological principle for new drugs [4]. Jateorhiza macrantha and its closely related species Jateorhiza palmata are the only two known species of medicinal plant in the genus Jateorhiza belonging to the Menispermaceae family- a family which also includes the medicinal and poisonous plant -St John's Wort. $J$. macrantha is widely used in ethnomedicine for the treatment of dysentery and diarrhea, parasitic infections, miscarriage, venomous stings and bites [510]. It is also use in the treatment of hypertension [11], and dysmenorrheal [12], weak libido, wound and ulcer $[9,10]$. Chemical compounds like: columbin, isocolumbin, plamarin, isojateorin, chasmanthin and palmatosides A are reported found in its closely related species Jateorhiza palmata [13] with scarce literature on similar reports for its closely related species Jateorhiza palmata [13] with scarce literature on similar reports for Jateorhiza macrantha. This study is aimed at evaluating the activity guided antidiarrheal fractionation of the aqueous ethanol extract of the leaves of Jateorhiza macrantha as a preliminary step toward the isolation and structural elucidation its antidiarrheal constituent(s) that could serve as useful leads in drug development. 


\section{MATERIALS}

Analytical grade reagents and chemicals used were products of BDH and/ or Sigma Aldrich unless otherwise stated. Loperamide hydrochloride was bought from Boldstep pharmaceutical shop Port-Harcourt, Rivers State Nigeria. Atropine sulphate (SigmaAldrich). The fresh leaves of Jateorhiza macrantha were sourced from Ijebu forests in Ore Ondo State, South Western Nigeria and authenticated by a Taxonomist Dr. Chukwuka S. Kanayo of the Department of Botany University of Ibadan with Voucher specimen number UIH 22610 deposited in the herbarium of same University. The leaves were air dried at room temperature, ground to fine powder and stored in an air tight container for further use. Swiss albino mice of both sex (6-7 weeks old) which weighed between $25-30 \mathrm{~g}$, and wistar albino rats of both sex $(150-200 \mathrm{~g})$ used in this study were collected from Department of Pharmacology, University of PortHarcourt, Nigeria. The animals were maintained under standard environmental conditions for acclimation for at least 1 week in the animal house before experiment. They had free access to food, and water ad libitum. The study protocol was approved by the institutional animal ethical Committee University of Port-Harcourt, Rivers State Nigeria (UPH/CEREMAD/REC/MM/60/036).

\section{METHODS}

\section{Preparation of the aqueous ethanol extract of Jateorhiza macrantha leaves}

This was done following a prior protocol established in our laboratory. Briefly, the aqueous ethanol extract (AEE) was obtained by exhaustive cold maceration of the powdered Jateorhiza macrantha leaves $(300 \mathrm{~g})$ at room temperature in $70 \%$ ethanol for 72 hours. The extraction solvent was replaced with fresh solvent at 24 hours interval during the 72 hours period of extraction. The filtrates obtained were pooled and concentrated using a rotary evaporator and further dried over the water bath at $<45^{\circ} \mathrm{C}$ to afford the crude $70 \%$ aqueous ethanol extract (AEE).

\section{Phytochemical Screening}

This was done using standard phytochemical screening reagents for the presence of the plant metabolites: alkaloids, saponins, tannins, flavonoids, phlobatannins, cyanogenic glycosides, cardiac glycosides, anthraquinones, tritepenoids, sugars, as reported $[14,15]$.

\section{Castor oil induced Diarrhea in mice}

This test was done according to the reported method [16, 17] with slight modification. Briefly, thirty mice were fasted for $18-24$ hours and divided into five groups with six animals in each group. First group received distilled water $10 \mathrm{ml} / \mathrm{kg}$ bw and the second received loperamide $(2 \mathrm{mg} / \mathrm{kg})$, serving as negative and positive respectively. Group 3, 4 and 5 received 100 , 200 and $400 \mathrm{mg} / \mathrm{kg}$ of the extract respectively. After 45 minutes, the animals received separately, $0.3 \mathrm{ml}$ of castor oil orally. The animals were kept in separate cages underplayed with a pre-weighed white paper. The severity of diarrhea was observed for 4 hours. The mean weight of pasty liquid or wet defecation (diarrheal droppings) and time of onset of diarrhea was determined and compared with the negative control group. The total score of diarrheal feces for the negative control group was considered as $100 \%$ non-inhibition effect. The percentage inhibition of diarrhea was calculated using the formula:

$\%$ inhibition of diarrhea $=\underline{\text { MWDC-MWDT } \times \quad 100}$

\section{MWDC}

Where,

MWDC is the mean weight of wet defecation due to diarrhea (negative) control group.

MWDT is the mean weight of wet defecation due to test group.

\section{Charcoal meal gastro-intestinal motility test}

The effect of the extract on small intestinal transit was studied in overnight fasted wistar albino rat (150- $200 \mathrm{~g}$ ) of either sex, which were divided into six groups containing four rats in each group including positive and negative controls. The negative control was given $2 \mathrm{ml}$ of DMSO while the positive control was given $10 \mathrm{mg} / \mathrm{kg}$ atropine sulphate orally. Other groups were given orally 100,125 , and $250 \mathrm{mg} / \mathrm{kg}$ body weight respectively. Five minutes after treatment, all rats were given $0.5 \mathrm{ml}$ of $5 \%$ charcoal in $5 \%$ gum acacia by oral route. All animals were sacrificed after $30 \mathrm{mins}$, the intestine removed, and the mean total length of the small intestine (TLSI), and the mean transit distance by the charcoal meal in the small intestine (TDCM) were measured. The peristaltic index (PI) and the percentage inhibition of intestinal motility were calculated as shown below $[17,18]$.

Peristaltic index $(\mathrm{PI})=\frac{\text { TDCM } \times 100}{\text { TLSI }}$

$\%$ Inhibition of intestinal motility $=\underline{\text { PIC-PIT } \times 100}$ PIC

Where,

TLSI is the mean total length of the small intestine.

TDCM is the mean distance covered by the charcoal meal in the small intestine.

PIC is the peristaltic index due to diarrhea (negative) control group.

PIT is the peristaltic index due to test group.

\section{STATISTICAL ANALYSIS}

All results are expressed as mean \pm standard error of mean (SEM). All statistical analyses were performed by one- way ANOVA followed by the 
Tukey HSD post-hoc test where $\mathrm{P}<0.05$ was regarded as statistical significant.

\section{RESULTS AND DISCUSSION}

The $70 \%$ aqueous ethanol extract obtained by cold maceration yield $3.98 \%$ w/w. From the phytochemical screening of the powdered leaves of $J$. macrantha, it was observed that whereas secondary plant metabolites like: saponins, triterpenoids, cyanogenic glycosides, cardiac glycosides, and anthraquinones were absent, phenolic constituents like tannins and flavonoids, carbohydrate derivatives in form of free and combined reducing sugars and alkaloids are evidently present. The observed trend in the phytochemical constituents is in agreement with that reported in the literature [10]. The crude $70 \%$ aqueous ethanol extract of $J$. macrantha (AEJML) significantly $(\mathrm{p}<0.05)$ decrease in a dose dependent manner, the diarrheal fecal mass in the castor oil induced diarrheal mice as shown in Table-1. At the highest dose of 400 $\mathrm{mg} / \mathrm{kg} \mathrm{bw}$, the anti-diarrheal effect, though slightly lower was not significantly different $(p>0.05)$ compared to that due to the reference drug loperamide at $2 \mathrm{mg} / \mathrm{kg}$ bw. At this highest dose, the AEJML also relatively delayed the onset of diarrheal episode more than the reference drug loperamide at $2 \mathrm{mg} / \mathrm{kg}$ bw though this effect was not significant ( $p>0.05)$. Thus, at the highest dose of $400 \mathrm{mg} / \mathrm{kg}$ bw the antidiarrheal activity perception or index of the AEJML could be seen as being comparable with the reference drug loperamide ( 2 $\mathrm{mg} / \mathrm{kg} \mathrm{bw}$ ). Similar trend was also observed for the charcoal meal gastro- intestinal anti-motility test. Here, all the test AEJML doses and the reference drug loperamide significantly inhibited the charcoal meal intestinal transit time compared to the control group as seen in Table-2 with a trend in the peristaltic index (PI) of: AEJML $250 \mathrm{mg} / \mathrm{kgbw}(\mathrm{PI}=24.79 \%)$ < loperamide 2 $\mathrm{mg} / \mathrm{kg}$ bw $(\mathrm{PI}=35.29 \%)<$ AEJML $125 \mathrm{mg} / \mathrm{kgbw}($ $\mathrm{PI}=61.23 \%)<$ AEJML $100 \mathrm{mg} / \mathrm{kgbw}(\mathrm{PI}=87.28 \%)<$ negative control group(PI $=87.60 \%)$. This trend is further buttressed by that for the percentage inhibition of GIT motility (see also Table-2) with the trend: AEJML $250 \mathrm{mg} / \mathrm{kgbw}(71.70 \%)$ >atropine sulphate 10 $\mathrm{mg} / \mathrm{kg}$ bw(59.71 \%) > AEJML $125 \mathrm{mg} / \mathrm{kgbw}(30.10$ $\%)>$ AEJML $100 \mathrm{mg} / \mathrm{kgbw}(\mathrm{PI}=0.37 \%)$. Thus, the AEJML could be seen as inhibiting both castor oil induced secretory diarrhea and gastro-intestinal motility or peristalsis. Depending on the cause, diarrhea may be marked by increased electrolyte secretion (secretory diarrhea), increased luminal osmolality (osmotic diarrhea), decreased electrolyte absorption and/or increased intestinal motility [17]. In line with this, the mechanism of action of any given anti-diarrheal agent could be by increasing the GIT transit time by way of inhibiting GIT motility as seen in the charcoal meal test or by inhibition of intestinal secretions and/or increasing the intestinal absorption of water and electrolytes [17]. Castor oil is a laxative due to its containing ricinoleic acid as the laxative principle which has been found to inhibit intestinal $\mathrm{Na}+\mathrm{K}+$ ATPase activity as well as stimulating the biosynthesis and release of endogenous prostaglandins responsible for diarrhea $[17,19,20]$. Several plant extracts and plant derived metabolites have been shown to exhibit anti-diarrhea activity by inhibiting castor oil induced secretory diarrhea or by the anticholinergic mechanism as seen in the charcoal meal anti-motility assay model [16-20]. Plant secondary metabolites like alkaloids, and phenolics like flavonoids, tannins and phenylpropanoids have been reported to exhibit antidiarrhea activity. Tannins and flavonoids are phenolic compounds occurring naturally in plants with ecological function. Flavonoids inhibit the release of prostaglandin by altering the production of lipooxygenase and cyclooxygenase I and II [21]. Thus flavonoids control the secretion induced by castor oil and make electrolytes absorption easier [22]. It was also reported that flavonoids [23] and tannin [24] have antidiarrheal property because they are able to inhibit the motility of the intestine. Therefore the presence of flavonoids, tannins and alkaloids in the leaves of $J$. macrantha in this study, offer a plausible rationale for the observed trend in the inhibitory effect on castor oil induced diarrhea and charcoal meal gastro intestinal motility.

Table-1: Effect of Jateorhiza macrantha Leaves $70 \%$ aqueous ethanol extract on Castor Oil-induced diarrhea in wistar albino mice

\begin{tabular}{|c|c|c|c|}
\hline Test Groups & $\begin{array}{c}\text { Time of diarrheal onset } \\
\text { (Mins) }\end{array}$ & $\begin{array}{c}\text { Weight (g) of fecal } \\
\text { mass }\end{array}$ & \% Diarrheal inhibition \\
\hline Negative Control $(10 \mathrm{ml} / \mathrm{kg} \mathrm{bw})$ & $20.50 \pm 1.70$ & $4.45 \pm 0.66$ & - \\
\hline Loperamide $(2 \mathrm{mg} / \mathrm{kg})$ & $28.75 \pm 5.85$ & $1.45^{\mathrm{a}} \pm 0.31$ & 67.42 \\
\hline AEJML $(100 \mathrm{mg} / \mathrm{kg})$ & $23.50 \pm 2.65$ & $3.85 \pm 0.47$ & 13.48 \\
\hline AEJML $(200 \mathrm{mg} / \mathrm{kg})$ & $27.75 \pm 5.32$ & $2.60 \pm 0.39$ & 41.57 \\
\hline AEJML $(400 \mathrm{mg} / \mathrm{kg})$ & $32.55 \pm 5.92$ & $1.58^{\mathrm{a}} \pm 0.30$ & 64.49 \\
\hline
\end{tabular}

Key: AEJML $70 \%$ aqueous ethanol extract of J. macrantha leaves, values are Mean \pm SEM, ${ }^{a}$ represent the values significantly difference $P<0.05)$ from the negative control. 
Table-2: Effect of the Jateorhiza macrantha Leaves $70 \%$ aqueous ethanol extract on charcoal meal intestinal transit time in wistar albino rats

\begin{tabular}{|l|c|c|c|c|}
\hline Groups & $\begin{array}{c}\text { Length of small } \\
\text { intestine }(\mathbf{c m})\end{array}$ & $\begin{array}{c}\text { Distance moved by } \\
\text { the charcoal meal(cm) }\end{array}$ & $\begin{array}{c}\text { Peristaltic } \\
\text { index PI }\end{array}$ & $\begin{array}{c}\text { Percentage inhibition } \\
\text { of GIT motility }\end{array}$ \\
\hline $\begin{array}{l}\text { Negative control } \\
(10 \mathrm{ml} / \mathrm{kg} \text { bw) }\end{array}$ & $42.81 \pm 3.78$ & $37.5 \pm 3.54$ & 87.60 & - \\
\hline $\begin{array}{l}\text { Atropine(10 } \\
\mathrm{mg} / \mathrm{kg} \mathrm{bw})\end{array}$ & $22.50 \pm 2.74$ & $7.94^{\mathrm{a}} \pm 1.63$ & 35.29 & 59.71 \\
\hline $\begin{array}{l}\text { AEJML(100 } \\
\text { mg/kg bw) }\end{array}$ & $22.56 \pm 2.74$ & $19.69^{\mathrm{a}} \pm 2.56$ & 87.28 & 0.37 \\
\hline $\begin{array}{l}\text { AEJML(125 } \\
\text { mg/kg bw) }\end{array}$ & $19.19 \pm 2.53$ & $11.75^{\mathrm{a}} \pm 1.98$ & 61.23 & 30.10 \\
\hline $\begin{array}{l}\text { AEJML(250 } \\
\text { mg/kg bw) }\end{array}$ & $29.25 \pm 3.12$ & $7.25^{\mathrm{a}} \pm 1.56$ & 24.79 & 71.70 \\
\hline
\end{tabular}

Key: AEJML $70 \%$ aqueous ethanol extract of J. macrantha leaves, values are Mean $\pm S E M,{ }^{a}$ represent the values significantly difference $P<0.05)$ from the negative control.

\section{CONCLUSION}

The observed anti- castor oil induced diarrhea and charcoal meal transit time inhibition effects of the aqueous ethanol extract of $J$. macrantha in this study, and the presence of flavonoids, tannins and alkaloids which are bioactive secondary metabiltes reported to have anti-diarrhea and anti-motility activities have confirmed scientifically the use of this plant in ethnomedicine for the treatment and management of diarrhea and related GIT illnesses. Further work is ongoing to isolate and elucidate the chemical structure of the pure form of the constituents in the aqueous ethanol extract of $J$. macrantha using spectroscopy techniques, and evaluate them for possible development into antidiarrheal medications for clinical use.

\section{REFERENCES}

1. Maiti, A. (2007). In Vivo Evaluation of Antidiarrheal Activity of the Seed of Swietenia Tropical. Journal Pharmaceutical Research. 6(2):711-716.

2. Fischer-Walker, C. L., Rudan, I., Liu, L., Nair, H., Theodoratou, E., Bhutta, Z. A., O’Brien, K. L., Campbell, H., \& Black, R. E. (2013). Global burden of childhood pneumonia and diarrhea. Lancet 381: 1405-1416.

3. Liu, L., Johnson, H. L., Cousens, S., Perin, J., Scott, S., Lawn, J. E., ... \& Mathers, C. (2012). Child Health Epidemiology Reference Group of WHO and UNICEF Global, regional, and national causes of child mortality: an updated systematic analysis for 2010 with time trends since 2000. Lancet, 379(9832), 2151-2161.

4. Gupta, P. D., \& Birdi, T. J. (2017). Development of botanicals to combat antibiotic resistance. Journal of Ayurveda and integrative medicine, 8(4), 266-275.

5. Dalziel, J. M. (1937). The useful plants of W. Tropical Africa, Crown agents for the colonies, London. 18-22.
6. Burkill, H. M. (1985). The useful plants of W. Tropical Africa. Royal Botanical Gardens, Kew. 4, 143.

7. Irvine, J. R. (1961).Woody Plants of Ghana. Oxford University press, London. 32-34.

8. Oliver, B. (1960). Medicinal plants in Nigeria. College of Arts, Science and Technology, Lagos. 139.

9. Ajayi, G. O., Salako, O. A., \& Mosebolatan, M. I. (2015). Anti-inflammatory and Analgesic activities of Jateorrhiza macrantha (Menispermaceae).International Journal of phytomedicine, 7(4):427-431.

10. Ajayi, G. O., Kadiri A. B., \& Ibiloye A. E. (2015). Pharmacognostic Characteristics of the West African Jateorhiza macrantha (Hook.F.) Exell \& Mendonça (Menispermaceae). International Journal of Pharmacognosy and Phytochemical Research, 7(5);1001-1006.

11. Aboubakar, O. B. F., Bella, N. M. T., Ngo, L. T. E., Bilanda, D. C., \& Dimo, T. (2012). Antihypertensive activity of Jateorhiza macrantha (Menispermaceae) aqueous extract on ethanolinduced hypertension in wistar. Int $J$ Pharm Pharm Sci, 4, 293-298.

12. Jiofack, T., Fokunang, C., Guedje, N., Kemeuze, V., Fongnzossie, E., Nkongmeneck, B. A., ... \& Tsabang, N. (2010). Ethnobotanical uses of medicinal plants of two ethnoecological regions of Cameroon. International Journal of Medicine and Medical Sciences, 2(3), 60-79.

13. Yonemitsu, M., Fukuda, N., Kimura, T., \& Komori, T. (1987). Studies on the Constituents of Jateorhiza palmata Miers (Colombo Root), II. Separation and Structure of Six New Furanoid Diterpene Glucosides: Palmatoside B, C, D, E, F, and G. Liebigs Annalen der Chemie, 1987(3), 193-197.

14. Houghton, P. J., \& Raman, A. (1999). Laboratory handbook for the fractionation of natural extracts. Chapman and Hall, London, UK. 
15. Harborne, J. B. (1998). Phytochemical methods-a guide to modern techniques of plant analysis. 3rd edition, Chapman and Hall, London, UK, 302.

16. Awouter, F., Neimegeers, C. J. E., Lenaeri, F. M., \& Janssen, P. A. J. (1978). Delay of castor oil diarrhoea in rats; A new way to evaluate inhibitors of prostanglandin's biosynthesis. Journal of Pharmaceutical Pharmacology; 30: 41-45

17. Tagne, M. A. F., Rékabi, Y., Noubissi P. A., Fankem, G. O., Akaou, H, Wambe, H., \& Kamgang, R. (2019). Evaluation of Antidiarrheal Activity of Aqueous Leaf Extract of Anogeissus leiocarpus on Castor Oil-Induced Diarrhea in Rats. American Journal of Biomedical Science \& Research, 3(1):1-8.

18. Pazhani, G. P., Subramanian, N., Arunchalam, G., Hemalatha, S., \& Ravichandran, V. (2001). Antidiarrheal potential of Elephantopus scaber Linn leaf extract. Ind drugs, 38(5): 269-271.

19. Rawat, P., Singh, P. K., \& Kumar, V. (2017). Evidence based traditional anti-diarrheal medicinal plants and their phytocompounds. Biomedicine and Pharmacotherapy; 96: 14531464.

20. Tadasse, W. T., Hailu A. E., Gurmu, A. E., \& Mechesso, A. F. (2014). Experimental assessment of antidiarrheal and antiscretory activity of $80 \%$ methanolic leaf extract of Zehneria scabra in mice. BMC Complementary and Alternative Medicine; 14(1):460-468.

21. Awad, A. B., Toczek, J., \& Fink, C. S. (2004). Phytosterols decrease prostaglandin releasein cultured P388D1/MAB macrophages. Prostaglandin Leukotrienes \& Essential Fatty acid, 70(6): 511-520.

22. Hamalainen, M., Nieminen, R., Asmaw, M. Z., Vuorela, P., Vapaatalo, H., \& Moilanen, E. (2011). Effects of Flavonoids on Prostaglandin E2 Production and on COX-2 and mPGES-1 Expressions in Activated Macrophages. Planta Medica, 77(13):1504-1511.

23. Di Carlo, G., Autore, G., Izzo, A. A., Maiolino, P., Mascolo, N., Viola, P., ... \& Capasso, F. (1993). Inhibition of intestinal motility and secretion by flavonoids in mice and rats: structure- activity relationships. Journal of Pharmacy and Pharmacology, 45(12), 1054-1059.

24. Ashok, P. K., \& Upadhyaya, K. (2012). Tannins are astringent. Journal of pharmacognosy and phytochemistry, 1(3), 45-50. 